\title{
Chemoautotrophy at the Expense of Thiosulphate: A Supplementary Nutritional Source to the Mangrove Clam-Polymesoda Erosa
}

\section{TresaRemya A Thomas}

CSIR-National Institute of Oceanography

\section{Tanya Singh}

2CSIR-National Institute of Oceanography

\section{Tamil S Kalaimani}

2CSIR-National Institute of Oceanography

\section{Nandakumar H Khadge}

CSIR-National Institute of Oceanography

\section{Mamatha S Shivaramu}

CSIR-National Institute of Oceanography

\section{Maria-Judith B-D Gonsalves}

CSIR-National Institute of Oceanography

LokaBharathi P Adhikesavan ( $\sim$ lokabharathiponnapakkam@gmail.com )

National Institute of Oceanography CSIR

\section{Research Article}

Keywords: Chemoautotrophy, 14C uptake, Polymesoda erosa, spawning phases, mangrove ecosystem

Posted Date: June 15th, 2021

DOl: https://doi.org/10.21203/rs.3.rs-561495/v1

License: (9) (i) This work is licensed under a Creative Commons Attribution 4.0 International License.

Read Full License 


\section{Abstract}

Chemolithoautotrophy is a primordial process, where chemical energy converts inorganic carbon to organic. The prevalence of chemosynthesis was examined in the mangrove clam, Polymesoda erosa, and the ambient sediment at Chorao Island, Mandovi estuary, Goa. The sediment system is reducing, organically rich, high in electron donors, acceptors, and inorganic carbon. This clam thrives by immersing $75-90 \%$ of its body in sulfidic sediments. Hence, it is hypothesized that it could have an adaptive mechanism like microbially mediated utilization of reduced sulfur compound, $\mathrm{S}_{2} \mathrm{O}_{3}{ }^{2-}$ (model compound) coupled to inorganic carbon uptake. During spawning, maximum carbonate uptake rates of 449 and 594 nmole $\mathrm{C} \mathrm{g}$ dry $\mathrm{wt}^{-1} \mathrm{~h}^{-1}$ were recorded in the gill and foot, respectively. Next generation sequencing revealed that Thiothrix and other sulfur oxidizers gathered from ambient sediment were present in gill, mantle and foot in the ratio 1:3:14 and 1:5:6, respectively. It is inferred that the clam and these associated bacteria could make an important contribution to chemosynthetic carbon fixation. The process could serve as an essential supplementary nutritional source especially during the physiologically feeble spawning phase. To the best of our knowledge, this is the first report of chemolithoautotrophic process in $P$. erosa of the family Cyrenidae.

\section{Introduction}

Mangrove swamps are one of the most productive ecosystems in the world occupying considerable part of the tropical and subtropical coastlines (Robertson 1986). High organic carbon input from the mangrove forests results in milli-molar sulphide enrichment in the sediment, mainly through anaerobic degradation via sulphate reduction (Attri et al. 2011; Fenchel and Riedl 1970; Laurent 2009; Nedwell et al. 1994; Sahoo and Dhal 2009). The mangrove surface sediment is generally aerobic to micro-aerobic followed by deeper anaerobic layers (Sahoo and Dhal 2009). These redox zones lead to the proliferation and functioning of chemoautotrophic bacteria which fix inorganic carbon using the energy derived from the oxidation of sulphide, ammonia, methane and metal ions (Oren 2010). Previous work has been restricted to mangrove molluscs such as Anondontia edentula, Lucina pectinata associated with chemoautotrophic bacteria (Christo et al. 2016; Frenkiel et al. 1996; Lebata 2001; Lebata and Primavera 2001). Such studies have been mainly from the mangroves along the Southeast Asia and Carribean Sea (Frenkiel et al. 1996; Durand et al. 1996; Pimenov et al. 2002).

Polymesoda erosa is widely distributed in the tropical and subtropical mangrove forests, the adults being more abundant in the high tide regions with 9-12 individuals $\mathrm{m}^{-2}$ (Clemente and Ingole 2006; Clemente and Ingole 2011; Ingole et al. 1994; Meehan 1982). It inhabits the sub-oxic to anoxic sediments in the intertidal zone. However, its potential for sulphide oxidation dependent inorganic carbon uptake (chemoautotrophy) is not yet understood. Moreover, unlike some clams from other reducing environments, $P$. erosa possesses a complete digestive system. Besides, this species also has rather small gills, which is uncharacteristic of strict chemosymbiotic bivalves (Morton 1976). Though primarily 
a filter feeder, its occurrence in organically rich, highly sulphidic and anoxic sediment prompted us to investigate the prevalence of chemoautotrophy mediated by the associated bacteria.

This study attempted to address the $\mathrm{S}_{2} \mathrm{O}_{3}{ }^{2-}$ (model compound) utilization and $\mathrm{HCO}_{3}{ }^{-}$uptake potential of the bacterial associates of $P$. erosa to indicate the occurrence of chemoautotrophy in this clam. Further, for the first time the above processes were measured in gill, foot and mantle tissues during different spawning phases under simulated laboratory conditions. This phenomenon has been described previously in other clams belonging to the families Lucinidae, Thyasiridae and Solemyidae. However, to the best of our knowledge this is the first report of microbial chemolithoautotrophy in $P$. erosa of family Cyrenidae.

\section{Methods}

\section{Sample Collection}

Adult specimens of $P$. erosa were hand-picked in triplicates from the mangrove sediments of Salim Ali bird sanctuary situated at Chorao Island, Mandovi estuary, Goa $\left(15^{\circ} 25^{\prime}-15^{\circ} 30^{\prime} \mathrm{N}\right.$ Lat and $73^{\circ} 45^{\prime} \mathrm{E}-73^{\circ} 59^{\prime} \mathrm{E}$ Long) (Fig. 1).

Ambient sediment samples up to $10 \mathrm{~cm}$ below sediment surface (bss) were also collected in triplicate and processed as detailed in Fernandes et al., (2012; 2013). The sampling was carried out intermittently from February 2013 to June 2015, covering pre-spawning (January-June), spawning (July-September) and post-spawning (October-December) (Rivonker 1995) (Supplementary Table 1). Morphometry of clams in different phases has been studied and given in (Supplementary Table 2).

Geochemical parameters were measured from the ambient sediment ( $0-2 \mathrm{~cm}$ bss) of $P$. erosa and overlying water. Water content, porosity and specific gravity of the sediment for each $2 \mathrm{~cm}$ depth up to 10 cm bss were measured by weight/volume method (ASTM 1978).

Eh and $\mathrm{pH}$ were measured on field using Sartorius PT-15 portable probe. Salinity was measured using a hand-held refractometer (ATAGO S/MillE) which was pre-calibrated to zero with distilled water.Overlying water was fixed for oxygen estimation as per Winkler's titrimetric method (Strckland and Tarson 1965). Approximately $1 \mathrm{~g}$ of sediment was fixed in $9 \mathrm{ml}$ of $2 \%$ zinc acetate solution for $\mathrm{H}_{2} \mathrm{~S}$ estimation. Subsequently, weight of the sediment was estimated after drying at $60^{\circ} \mathrm{C}$. Pore water for nutrient analyses was extracted in the laboratory as detailed in Fernandes et al. (2012; 2013). Sulphur content in the pore-water was measured iodometrically (referred as 'iodometric sulphur') prior to dilution (Hansen 1973). $\mathrm{H}_{2} \mathrm{~S}$ content in the fixed sediment sample was measured by Pachmayr's method (Truper and Schlegel 1964). TOC was determined by dichromate digestion by calorimetric method (Azam and Sajjad 2005).

\section{Maintenance of clams in the laboratory and tissue sample treatment}


The clams were maintained at the prevailing ambient temperature of $30 \pm 2{ }^{\circ} \mathrm{C}$ in an aerated tank containing a thin bed of mangrove sediments filled with adequate volume of water collected from the sampling site. After a week of acclimatization, their weight, length, width and height were recorded. The shells were subsequently opened and each clam's tissue was washed with pre-filtered autoclaved $50 \%$ sea water. Further, they were dissected under sterile conditions and gill, foot and mantle tissues were separated. Care was also taken to avoid all contamination across the tissues. Subsequently, about $1 \mathrm{~g}$ of wet weight of each tissue was homogenized in $1 \mathrm{ml}$ of $50 \%$ pre-filtered and autoclaved sea water and made up to $10 \mathrm{ml}$ and then serially diluted for measuring the $\mathrm{S}_{2} \mathrm{O}_{3}{ }^{2-}$ uptake rate and bacterial abundance. Wet weight was later converted to dry weight by drying at $60{ }^{\circ} \mathrm{C}$ till constant weight. Each tissue of $0.1 \mathrm{~g}$ was used separately for measuring $\mathrm{HCO}_{3}$-uptake rate.

TBC was estimated as detailed in Hobbie et al. (1977). TVCa and TVCan were estimated as detailed in Kogure et al. (1984) and LokaBharathi et al. (1988; 1999).

\section{CFU-agar shake technique}

Agar shake method was used to enumerate $\mathrm{S}_{2} \mathrm{O}_{3}{ }^{2-}$ utilizing bacteria from tissue after 30 to 60 days incubation in Leiske's medium with pH 8.0 0.2 at room temperature (LokaBharathi et al. 1988; Hansen 1973; LokaBharathi 1989).

\section{MPN of $\mathrm{S}_{2} \mathrm{O}_{3}{ }^{2-}$ utilizing bacteria}

Colorimetric estimation in multi well plates was used for assessing the MPN (most probable numbers) of $\mathrm{S}_{2} \mathrm{O}_{3}{ }^{2-}$ utilizing bacteria (LokaBharathi et al. 1988; Hansen 1973; LokaBharathi 1989) (Supplementary Fig. 1).

\section{Estimation of $\mathrm{S}_{2} \mathrm{O}_{3}{ }^{2}$-and $\mathrm{HCO}_{3}{ }^{-}$uptake rate in tissues}

MPN (most probable numbers) method used for measuring $\mathrm{S}_{2} \mathrm{O}_{3}{ }^{2-}$ was suitably adopted for colorimetric estimation in multi well plates for assessing the activity of $\mathrm{S}_{2} \mathrm{O}_{3}{ }^{2-}$ utilizing bacteria (LokaBharathi et al. 1988; Hansen 1973; LokaBharathi 1989) (Supplementary Fig. 1). Microbial uptake of inorganic carbon in tissues was measured by $\mathrm{NaH}^{14} \mathrm{CO}_{3}$ uptake $\left(5 \mu \mathrm{Ci} \mathrm{ml}^{-1}\right.$, Board of radiation and isotope technology, BRIT, Navi Mumbai, India), adopting the methods described earlier (Nelson et al. 1989; Tuttle and Jannasch 1977). The estimation of $\mathrm{S}_{2} \mathrm{O}_{3}{ }^{2-}$ and $\mathrm{HCO}_{3}$-uptake rate in tissues is given in detail as supplementary document 1.

\section{DNA extraction from clam tissues and sediment for NGS analysis}

Total DNA was extracted from ca.15 mg of tissue representing gill, foot and mantle of P.erosa usingDNeasy Blood and Tissue DNA isolation kit (Qiagen). The sample clam used for DNA extraction belonged to post-spawning phase. Similarly total DNA was extracted in replicates from ca. 
$500 \mathrm{mg}$ of ambient surface sediment using the Fast DNA ${ }^{\mathrm{R}}$ Spin kit. The quality of DNA samples was checked using Nanodrop. The samples were further sent to Genotypic Technology, Bangaluru, India for NGS analyses with $16 \mathrm{~S}$ rRNA as bacterial marker gene for taxonomy.

\section{Pyrosequencing using Illumina platform}

Library preparation was performed at Genotypic Technology's Genomics facility (Bangaluru, India). Nanodrop quantified DNA (25 ng) was used for amplifying V3-V4 region of 16S rRNA gene. The libraries were further sequenced using Illumina Myseq and data analysis was performed using QIIME (Quantitative Insights Into Microbial Ecology) (Caporaso et al 2010). Generated Sequence data were submitted through SRA in Genbank (NCBI) with the SRA Accession ID: SRP075329.

\section{Statistical Analysis}

PERMANOVA (Permutational Multivariate Analyses of Variance) was implemented to check if there is any significant variation among $\mathrm{S}_{2} \mathrm{O}_{3}{ }^{2-}$ and $\mathrm{HCO}_{3}{ }^{-}$uptake rates across tissues and phases using PRIMER (Plymouth Routines In Multivariate Ecological Research) version 6.1.10.

\section{Results}

P. erosa is generally found in the proximity of vegetation. The pre, post and spawning phases of the clam more or less overlap with the pre-monsoon, post-monsoon and monsoon seasons. The body mass reduced by $27 \%$ from an average of $134 \pm 44 \mathrm{~g}$ during pre-spawning to $98 \pm 6 \mathrm{~g}$ during post-spawning (Supplementary Table 2).

Distribution of P.erosa. The clams were present at an average density of 10 individuals $\mathrm{m}^{-2}$ in the mid tide and high tide regions of the Chorao mangrove swamp. Adult clams with maximum size were observed during the peak maturation period (June). Mean weight, length, height and width of the mature adult clam during pre-spawning phase were $134 \pm 44 \mathrm{~g}, 7 \pm 0.7 \mathrm{~cm}, 6 \pm 0.9 \mathrm{~cm}$ and $4 \pm 0.5 \mathrm{~cm}$, respectively (Supplementary Table 2).

Geochemical and geotechnical properties of the ambient sediment of P. erosa. Salinity varied from a mean of $2.1 \pm 3$ during spawning to $27.8 \pm 4$ during post-spawning. The mangrove sediment $\mathrm{pH}$ varied from mildly acidic $(6.63 \pm 0.3)$ during the post-spawning to alkaline $(7.52 \pm 0.6)$ during the spawning period. In contrast, the lowest Eh in sediment was recorded during the spawning period (Supplementary Table 3).

Concentration of electron donors such as $\mathrm{H}_{2} \mathrm{~S}$ in sediment, iodometric sulphur and $\mathrm{NH}_{4}{ }^{+}$in pore-water was the highest during the spawning period constituting an average of $385 \pm 394.42,161 \pm 244.13$ and $142 \pm 217.09 \mu \mathrm{M}$, respectively with high standard deviations. On the other hand, the lowest concentrations of the reduced sulphur compounds were detected during the post-spawning period $\left(\mathrm{H}_{2} \mathrm{~S}\right.$ : 
$35 \mu \mathrm{M}$, iodometric sulphur: $36 \mu \mathrm{M})$. Lowest $\mathrm{NH}_{4}{ }^{+}(3 \mu \mathrm{M})$ was measured during pre-spawning (Supplementary Table 3).

The concentrations of potential electron acceptors $\mathrm{O}_{2}$ and $\mathrm{NO}_{3}{ }^{-}$during the seasons were in the order spawning > pre-spawning > post-spawning. During the spawning period, $\mathrm{O}_{2}$ and $\mathrm{NO}_{3}{ }^{-}$concentrations reached up to $64 \mu \mathrm{M}$ and $12 \mu \mathrm{M}$, respectively. On the other hand, $\mathrm{NO}_{2}{ }^{-}$concentration up to $0.7 \mu \mathrm{M}$ was recorded during pre-spawning with high standard deviations. It further showed an exponential decrease through spawning and post-spawning periods. In general, all the three electron acceptors were low during the post-spawning period (Supplementary Table 3). The highest sedimentTOC (total organic carbon) of $40.48 \pm 0.25 \mathrm{mg} \mathrm{C} \mathrm{g}^{-1}$ dry sediment was during the post-spawning period and the lowest of $6.93 \pm$ $2.16 \mathrm{mg} \mathrm{C} \mathrm{g}^{-1}$ dry sediment was during the pre-spawning period (Supplementary Table 3 ).

Specific gravity of the sediment measured up to $10 \mathrm{~cm}$ bss varied from $1.67 \pm 0.9$ at $4-6 \mathrm{~cm}$ bss to 2.44 \pm 0.3 at $6-8 \mathrm{~cm}$ bss. The corresponding reduction in porosity to $28.4 \pm 21 \%$ was recorded at $4-6 \mathrm{~cm}$ bss. Water content at this depth was relatively high up to $8.6 \pm 0.2 \%$ compared to upper and lower layers (Supplementary Table 4).

Bacterial abundance in tissues. Total bacterial numbers (TBC) were an order higher in pre-spawning phase compared to spawning and post-spawning phases. Maximum colony forming units (CFU) were retrieved from the foot during all the three phases. Spawning phase was generally characterized by low bacterial numbers except in the mantle which possessed relatively high number of TBC. Total aerobic viable counts (TVCa) and Total anaerobic viable counts (TVCan), outnumbered that of gill and foot. Large standard deviations were observed in most of the bacterial parameters during all the three phases (Table 1).Among the TVCan of gill, foot and mantle tissues of $P$. erosa, Thiothrix like filaments of 50 to $100 \mu \mathrm{m}$ length were prominent.Gill and foot tissues generally possessed filaments with visible cross walls whereas ensheathed filamentous cells were dominant in mantle. Intermittent enlarged cells with intracellular inclusions possibly storing sulphur granules were observed in gill and foot (Fig. 2). 
Table 1

Abundance of bacteria in gill, foot and mantle tissues of $P$. erosa during different spawning phases (Numbers are given as log values $\mathrm{g} \mathrm{wt}^{-1}$ ).

TBC

TVCa

TVCan

CFU

MPN

\section{Pre-spawning}

$\begin{array}{llllll}\text { Gill } & 9.81 \pm 10.00 & 8.80 \pm 8.88 & 9.18 \pm 9.44 & 4.05 \pm 4.33 & 5.43 \pm 5.27 \\ \text { Foot } & 9.26 \pm 9.52 & 8.85 \pm 8.89 & 9.16 \pm 9.40 & 5.68 \pm 5.98 & 5.17 \pm 3.30 \\ \text { Mantle } & 9.71 \pm 9.93 & 8.63 \pm 8.68 & 8.63 \pm 8.70 & 3.94 \pm 4.24 & 5.19 \pm 4.63\end{array}$

\section{Spawning}

\begin{tabular}{llllll} 
Gill & $8.10 \pm 7.75$ & $7.87 \pm 7.46$ & $7.86 \pm 7.63$ & $2.51 \pm 2.52$ & $5.10 \pm 5.09$ \\
Foot & $8.08 \pm 7.56$ & $7.77 \pm 7.46$ & $7.81 \pm 7.58$ & $2.98 \pm 3.10$ & $4.62 \pm 4.33$ \\
\hline Mantle & $8.20 \pm 8.00$ & $7.92 \pm 7.72$ & $7.98 \pm 7.77$ & $2.60 \pm 2.72$ & $4.96 \pm 4.99$
\end{tabular}

Post-Spawning

\begin{tabular}{llllll} 
Gill & $9.00 \pm 8.57$ & $7.34 \pm 7.49$ & $8.16 \pm 8.22$ & $3.04 \pm 3.11$ & $4.40 \pm 0.00$ \\
Foot & $8.84 \pm 8.53$ & $8.09 \pm 8.22$ & $7.68 \pm 7.48$ & $3.26 \pm 2.78$ & $4.18 \pm 0.00$ \\
\hline Mantle & $8.87 \pm 0.00$ & $6.70 \pm 0.00$ & $8.10 \pm 0.00$ & $3.04 \pm 3.18$ & $5.92 \pm 0.00$
\end{tabular}

TBC: Total Bacterial Count, TVCa: Total Viable Count (aerobic), TVCan: Total Viable Count (anaerobic); MPN: Most Probable Number (thiosulphate utilizers); CFU: Colony Forming Units (microaerophilic thiosulphate utilizing bacteria) TBC ( $n=7,8,7) ;$ TVCa $(n=8,8,7)$; TVCan ( $n=8,8,7)$; CFU $(30,24,28)$; MPN $(n=9,8,8)$ for gill, foot and mantle, respectively during pre-spawning phase. TBC $(n=6,6,5)$; TVCa $(n=6,6,6)) ;$ TVCan $(n=6,6,6) ;$ CFU $(n=15,14,11)$; MPN $(n=6,4,4)$ for gill, foot and mantle, respectively during spawning phase. TBC $(n=2,2,1)$; TVCa $(n=2,2,1)$; TVCan $(n=2,3,1)$; CFU $(n=9,9,6)$; MPN $(n=1,1,1)$ for gill, foot and mantle, respectively during post-spawning phase.

MPN of $\mathrm{S}_{2} \mathrm{O}_{3}{ }^{2-}$ utilizing bacteria was estimated in liquid Leiske's medium. The MPN ranged from $10^{4} \mathrm{~g}^{-}$ ${ }^{1} \mathrm{dry}$ wt. in gill to nearly $10^{6} \mathrm{~g}^{-1} \mathrm{dry}$ wt.in mantle during post spawning. These tubes mostly served to estimate the $\mathrm{S}_{2} \mathrm{O}_{3}{ }^{2-}$ utilization in tissues and sediments.

\section{Microbial community structure of gill, foot and mantle of $P$. erosa and ambient surface sediment.}

Proteobacteria was the most abundant in gill and sediment while Bacteroidetes dominated in foot and mantle. Proteobacteria from gill and sediment clustered together depicting close phylogenetic relatedness whereas that from foot and mantle formed another related group (Fig. 3).

Commonality in the reads between sediment and tissues revealed that Thiothrix sp and other sulphur oxidisers could be harvested from the ambient system (Fig. 4). Table 2 shows the comparative distribution of Thiothrix andother chemoautotrophic genera in these tissues. It also shows that Thiothrix 
tags in tissue were relatively higher than other chemoautotrophic sulphur oxidizers.NGS (next generation sequence)analyses also showed the dominance of Thiothrix sp among bacteria, and their large standard deviations confirm their heterogenous and patchy distribution. They were present in gill, mantle and foot in the ratio $1: 3: 14$ and $1: 5: 6$, respectively.

Table 2

Relative percentage of dominant obligate/facultative chemoautotrophic genera in the clam tissues

\begin{tabular}{|llll|}
\hline Chemoautotrophic genera & Gill & Foot & Mantle \\
& $(\%)$ & & \\
\hline Thiorhodospira & 0.004 & 0.005 & 0.034 \\
\hline Thiocapsa & 0.007 & 0.112 & 0.185 \\
\hline Thiothrix & $\mathbf{0 . 0 3 9}$ & $\mathbf{0 . 5 3 8}$ & $\mathbf{0 . 1 1 4}$ \\
\hline Methylophaga & $\mathbf{0 . 5 0 1}$ & $\mathbf{0 . 0 2}$ & $\mathbf{0 . 2 1 7}$ \\
\hline Thiorhodococcus & $\mathbf{0 . 0 1 7}$ & $\mathbf{0 . 0 2 4}$ & $\mathbf{0 . 1}$ \\
\hline Paracoccus & 0.004 & 0.01 & 0.191 \\
\hline Shewanella & $\mathbf{0 . 3 2 8}$ & $\mathbf{0 . 0 1 3}$ & $\mathbf{0 . 2 4 2}$ \\
\hline Marichromatium & 0.002 & 0.007 & 0.00 \\
\hline Thiomonas & $\mathbf{0 . 3 0 5}$ & $\mathbf{0 . 0 1 6}$ & $\mathbf{0 . 0 5 2}$ \\
\hline Planctomyces & 0.004 & 0.031 & 0.269 \\
\hline Nitrosococcus & 0.064 & 0.007 & 0.095 \\
\hline Thioalkalivibrio & 0.001 & 0.008 & 0.011 \\
\hline Marinobacter & 0.063 & 0.018 & 0.052 \\
\hline Pseudomonas & 0.033 & 0.007 & 0.108 \\
\hline
\end{tabular}

$\mathrm{S}_{2} \mathrm{O}_{3}{ }^{2-}$ uptake rate in tissues. In the pre-spawning phase, gill and foot utilized $\mathrm{S}_{2} \mathrm{O}_{3}{ }^{2-}$ throughout incubation and the former showed the highest rate of 1.1 mmole g dry $\mathrm{wt}^{-1} \mathrm{~h}^{-1}$. In contrast, mantle exhibited the lowest uptake rate 0.3 mmole $g$ dry $\mathrm{wt}^{-1} \mathrm{~h}^{-1}$ during pre-spawning. Contrary to the prespawning phase, spawning was characterized by lower $\mathrm{S}_{2} \mathrm{O}_{3}{ }^{2-}$ utilization by all the tissues. Yet,during spawning, gill exhibited relatively higher uptake rate of 0.16 mmole $g$ dry $\mathrm{wt}^{-1} \mathrm{~h}^{-1}$ than the other two tissues (Fig. 5).

During the post spawning phase, gill and foot regained their uptake efficiency. These tissues consumed $\mathrm{S}_{2} \mathrm{O}_{3}{ }^{2-}$ at a higher rate of 0.6 mmole $\mathrm{g}$ dry $\mathrm{wt}^{-1} \mathrm{~h}^{-1}$ and $0.4 \mathrm{mmole} g$ dry $\mathrm{wt}^{-1} \mathrm{~h}^{-1}$, respectively than 
during the spawning phase. On the other hand, mantle showed a net release of $\mathrm{S}_{2} \mathrm{O}_{3}{ }^{2-}$ (Fig. 5). Experiments to measure $\mathrm{HCO}_{3}{ }^{-}$uptake rates at the expense of $\mathrm{S}_{2} \mathrm{O}_{3}{ }^{2-}$ showed interesting variations.

$\mathrm{HCO}_{3}{ }^{-}$uptake ( ${ }^{14} \mathrm{C}$ uptake) rate in tissues. In contrast to $\mathrm{S}_{2} \mathrm{O}_{3}{ }^{2-}$ uptake, maximum $\mathrm{HCO}_{3}{ }^{-}$uptake rate of 594 nmole $C$ g dry wt ${ }^{-1} \mathrm{~h}^{-1}$ with a large standard deviation of \pm 605 was measured during spawning

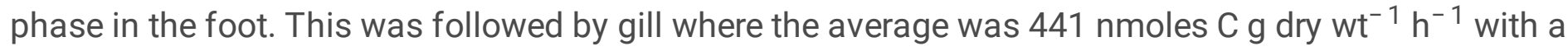
standard deviation of \pm 156 (Fig. 6). On the other hand, mantle showed maximum $\mathrm{HCO}_{3}{ }^{-}$uptake of 116 nmole $\mathrm{C} \mathrm{g}$ dry $\mathrm{wt}^{-1} \mathrm{~h}^{-1}$ during pre-spawning and the lowest during spawning. Mantle was able to uptake $\mathrm{HCO}_{3}{ }^{-}$at a relatively higher rate of $68 \mathrm{nmole} \mathrm{g}$ dry wt $^{-1} \mathrm{~h}^{-1}$ than other tissues during post-spawning in spite of the net $\mathrm{S}_{2} \mathrm{O}_{3}{ }^{2-}$ release. However, the mean $\mathrm{HCO}_{3}{ }^{-}$uptake rate of tissues was low during the postspawning period (Fig. 6).

\section{Discussion}

The sediment texture was silty clay which is known to be highly suitable for bacterial multiplication and activity (Chau et al. 2011; Fallon et al. 1983; Sahoo et al. 2011). This habitat could also be suitable for the clams, as they are also dependent on the sediment bacteria for useful association to thrive in the reducing sub-oxic sediment (Dubilier et al. 2008). The geotechnical properties of these sediments are found to be altered in the presence of the clam. The specific gravity $(1.6 \%)$ and porosity $(28.6 \%)$ get reduced, thus increasing the water content (8.6\%) especially at $4-6 \mathrm{~cm}$ bss (Supplementary Table 4). This could be attributed to the bio-turbating activity of the clam and perhaps other thiobiotic fauna (Sahoo et al. 2011). All these physical changes brought about by the clam could affect the geotechnical properties of the sediment which in turn affect the responses by both free and associated bacteria and physiology of the clam. Such effect of fauna on the physical properties of the sediment had been mentioned earlier by Rhoads and Boyer (Rhoads and Boyer 1982).

Chemosynthetic potential of the clam, $P$. erosa at the expense of reduced sulphur compounds could be attributed to its bacterial associates. The intensity of the process could vary with the three phases of the clam. The phase wise variation can also result from the interaction with ambient environmental parameters. Since the biological rhythm of spawning, overlaps with the monsoon, there could be interesting variations in the pertinent variables promoting dark carbon fixation.

Four different fractions of bacterial counts showed significant variation across phases (Supplementary Table 5). The TBC comprise of living, dormant and even dead forms (Naik et al. 2016). In the tissues they ranged from $10^{8}$ to $10^{9}$ cellsg dry $\mathrm{wt}^{-1}$ with maximum numbers in the gill during the pre-spawning phase (Table 1). Since gills are the principle filtration organ, their direct contact with ambient water facilitates the accumulation of highest number of bacteria per gram of tissue (Dando et al. 1985; Duperron et al. 2013). However, the bacterial fractions enumerated as direct viable counts (TVCa and TVCan) are able to participate in the activity either aerobically or anaerobically. These formed $10 \%$ of TBC with anaerobes being marginally higher than aerobes. It is probable that a greater portion of them are facultative aerobes 
or anaerobes as nearly same orders have been encountered under both the conditions. Only about 0.0001 to $0.001 \%$ have been able to form colonies.

Pre-spawning phase was characterized by the occurrence of large adult clams with maximum body mass of $134 \pm 44 \mathrm{~g}$ (Supplementary Table 2), harboring high number of CFU of thiosulphate utilizing bacteria up to $10^{6} \mathrm{CFU} \mathrm{g}$ dry $\mathrm{wt}^{-1}$ (Table 1 ). This fraction is viable, able to form colonies and perhaps even actively participate in improving the physiology of the clam in preparation for the subsequent spawning phase. Pre-spawning also coincided with the pre-monsoon which is reported to have the highest chl a (Clemente and Ingole 2009) and also perhaps high abundance of bacteria in the Mandovi estuary where the study site is located. Thus, high food supply enhances filter feeding which in turn could lead to a large bacterial population especially in gill tissue during this phase. In sync with the body mass reduction of clam observed during spawning, decrease in TBC to $10^{8}$ cells $\mathrm{g} \mathrm{dry} \mathrm{wt}^{-1}$ was also noted (Table 1) (Rivonker and Parulekar 1995). High heterogeneity in the distribution was observed in the TBC of gill, TVCa of gill and foot, TVCan and CFU of all the three tissues, suggesting patchy distribution. However, significant variations of bacterial parameters across tissues was absent, except for CFU $(P<0.01)$ (Supplementary Table 5). Earlier studies have also mentioned that sulphur oxidizers preferably occupy certain favorable regions in the invertebrate tissues (Dando et al. 1985). The CFU retrieved under microaerobic condition in the mineral media in this study were 1 to 3 times less than those retrieved under aerobic condition as reported earlier by Podgorsek and Imhoff (1999). Most probable numbers are more than CFU by an order. While CFU facilitate isolation of sulphur oxidizers for future work, MPN help estimate community numbers and their activity in near in situ conditions. Besides, there is more scope for encountering new lineages of these in liquid media.

Proteobacteria was the most abundant in gill and sediment while Bacteroidetes dominated in foot and mantle in metagenomic community analysis. Since Proteobacteria from various chemosynthetic ecosystems like hydrothermal vents and cold seeps are key players in chemoautotrophy (Thomas et al. 2018). Such observation in mangrove ecosystems also emphasizes their important contribution in dark carbon fixation.

Branched filamentous facultative anaerobic Thiothrix like cells of 2 different morphotypes with and without sheath were observed in the total bacterial community of gill, foot and mantle tissues (Fig. 2). Since Thiothrix species were present in the metagenomic community of all the three tissues and in the ambient sediment (Fig. 4, Table 2), it was assumed that they were free-living forms which were laterally acquired from the sediment. Earlier studies on Thiothrix species showed that they can be free living or associates/symbionts (Dattagupta et al. 2009; Distel et al. 1988; Odintsova et al. 1993). Table 2 also shows that Thiothrix tags in tissue were relatively higher than other chemoautotrophic sulphur oxidizers. Apart from being a mixotroph, the high efficiency of Thiotrhix cells to uptake inorganic carbon to perform chemolithoautotrophy can out compete other bacteria in establishing their growth in the host tissue (Nielsen et al. 2000). Presence of common chemoautotrophic OTUs in clam tissues and sediment suggests horizontal transmission. Such horizontal or environmental transmission of chemoautotrophic 
bacteria were also observed in the lucinid clams Codakia orbicularis, Lucinoma aequizonata and family Thyasiridae (Gros et al. 1996; Gros et al. 1999).

Thiosulphate uptake measured in the tissues is assumed to be due to the enzymes in the tissue and/or associated bacteria. PERMANOVA (Permutational Analysis of Variance) analysis confirms the significant variation in $\mathrm{S}_{2} \mathrm{O}_{3}{ }^{2-}$ uptake rate in gill, foot and mantle tissues across different phases

$(P=0.001)$ (Supplementary Table 6). Though the process was observed through the three spawning

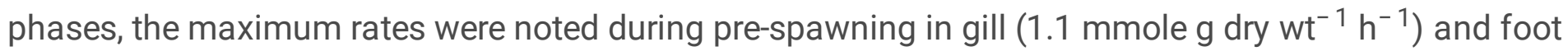

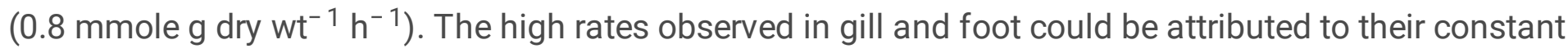
and prolonged interaction with water and sediment bacteria, respectively. The rates then reduced by 1 to 2 orders during spawning and later regained during post-spawning (Fig. 5). Mantle displayed net release of $\mathrm{S}_{2} \mathrm{O}_{3}{ }^{2-}$ during post-spawning. This release could perhaps be attributed to the stored $\mathrm{S}_{2} \mathrm{O}_{3}{ }^{2-}$ in the tissue that gets released before subsequent uptake. Such alternating periods of release and uptake have also been noted by other workers in chemoautotrophic snails and bivalves (Beinart et al. 2015; Ott et al. 1998; Vrijenhoek 2010). Thiosulphate production in these tissues is governed by aerobic oxidation of stored sulphide, sulphite and sulphur in the absence of external sulphide (Arndt et al.2001). Earlier studies on the mangrove clam Anodontia edentula also showed that $\mathrm{H}_{2} \mathrm{~S}$ is drawn through the foot and transferred to blood which is later carried and delivered to endosymbiotic bacteria in the gills. Studies have also shown that in the case of chemoautotrophic symbiosis, the foot of the clam penetrates deeper into the sediment to obtain sulphide (Lebata 2001). Though the average thiosulphate utilization across the three phases was higher in the gill, the study also emphasizes the potential of foot and mantle in utilizing the reduced sulphur compound in the mangrove ecosystem. Significant variation in $\mathrm{S}_{2} \mathrm{O}_{3}{ }^{2-}$ uptake rate was not detected among tissues during pre-spawning and spawning but was evident during post-spawning (Supplementary Table 7). The rate of $\mathrm{S}_{2} \mathrm{O}_{3}{ }^{2-}$ uptake has also been examined per gram wet tissue for comparison with the earlier studies. Of the total number of values measured at different time intervals in triplicate with different tissues, the average rate of 0.1 mmole g wet wt ${ }^{-1} \mathrm{~h}^{-1}$ obtained with the gill tissue at 10 minutes incubation was used for comparison. Gill of Solemya reidi from a sludge outfall in California was able to uptake 0.52 to $1.45 \mu$ mole g wet $\mathrm{wt}^{-1} \mathrm{~h}^{-1}$ (Anderson et al. 1987). This rate is 2 to 3 orders less than the maximum rate shown by gills of $P$. erosa. Similarly, the provannid snails Alviniconcha sp. and Ifremeria nautilei and the mussel Bathymodiolus brevior collected from the vents of Eastern Lau Spreading Centre were able to oxidize $\mathrm{S}_{2} \mathrm{O}_{3}{ }^{2-}$ within the range of 4.02 to $5.6 \mu$ mole g wet $\mathrm{wt}^{-1} \mathrm{~h}^{-1}$ (Beinart et al. 2015). Again, these rates are two orders less than the maximum rate shown by $P$. erosa emphasizing its efficiency in decreasing the ambient sulphide.

In contrast to $\mathrm{S}_{2} \mathrm{O}_{3}{ }^{2-}$ uptake rate, PERMANOVA analysis did not show significant variation in $\mathrm{HCO}_{3}{ }^{-}$uptake rate in tissues across phases (Supplementary Table 7). In tissues, $\mathrm{HCO}_{3}{ }^{-}$uptake rate varied from 1.6 to 594 nmole $\mathrm{Cg}$ dry $\mathrm{wt}^{-1} \mathrm{~h}^{-1}$ and did not follow the same seasonal trend as in $\mathrm{S}_{2} \mathrm{O}_{3}{ }^{2-}$ uptake rate. Maximum rates of carbon uptake were measured during spawning period in gill and foot. Though 
foot showed peak rate of 594 nmole $\mathrm{Cg}$ dry $\mathrm{wt}^{-1} \mathrm{~h}^{-1}$, with higher deviation, gill was relatively more homogenous in its activity with less deviation (Fig. 6).

In spite of the low $\mathrm{S}_{2} \mathrm{O}_{3}{ }^{2-}$ uptake rate during spawning, the high $\mathrm{HCO}_{3}{ }^{-}$uptake suggests that either it depends on the stored sulphur compounds (Caro et al., 2007) or other electron donors like $\mathrm{CH}_{4}$ and $\mathrm{NH}_{4}{ }^{+}$. This phase was also characterized by highest concentrations of electron donors $\left(\mathrm{H}_{2} \mathrm{~S}: 385 \pm 394 \mu \mathrm{M}\right.$, lodimetric sulphur: $161 \pm 244 \mu \mathrm{M}$ and $\left.\mathrm{NH}_{4}{ }^{+}: 143 \pm 217 \mu \mathrm{M}\right)$ and acceptors $\left(\mathrm{O}_{2}: 64 \pm 25 \mu \mathrm{M}\right.$ and $\mathrm{NO}_{3}{ }^{-}: 12 \pm$ $4 \mu \mathrm{M})$ in the Chorao mangrove sediment. Both the physiology of the clam and the geochemistry of the ambient water and sediment facilitate the $\mathrm{HCO}_{3}$ - uptake in tissue during the spawning phase. The physiology of the clam helps in converting the stored sulphur compounds to $\mathrm{S}_{2} \mathrm{O}_{3}{ }^{2-}$ to help in $\mathrm{CO}_{2}$ fixation when external supply of $\mathrm{H}_{2} \mathrm{~S}$ dissipates. Another aspect relevant to spawning phase is the high rate of dissolution of $\mathrm{CO}_{2}$ and $\mathrm{O}_{2}$ due to freshening of waters during monsoon which coincides with spawning. Continuous supply of potential electron acceptor $\mathrm{O}_{2}$ and the carbon source $\mathrm{CO}_{2}$ facilitates carbon fixation by bacterial associates. Since spawning retards the feeding rate in bivalves, the symbiont/associate based chemoautotrophy could emerge as an additional complementary nutritional source to the host.

Such complementary nutritional sources can also be accomplished by anaplerotic reactions. Anaplerotic reactions generate some of the key intermediates of the citric acid cycle which are also used as precursors in other biosynthetic pathways to produce glucose, fatty acids and essential amino acids (Owen et al. 2002). Some bacteria like the green sulphur bacteria Chlorobaculum tepidum can utilize $\mathrm{CO}_{2}$ and organic molecules like acetate and pyruvate during mixotrophic growth. This is accomplished through a unique carbon and energy metabolism (Feng et al. 2010). The bacteria produce acetyl CoA from acetate. Further, Pyruvate:ferredoxin oxidoreductase convert acetyl-CoA and $\mathrm{CO}_{2}$ to pyruvate. This reaction is promoted by reduced ferredoxin generated during phototrophic growth. Here, anaplerotic pathway maintains the interaction of autotrophic and heterotrophic pathways and drives mixotrophy more efficiently. Relevance of anaplerotic pathways in carbon uptake was also noted in the Roseobacter clade of marine bacteria (Tang et al. 2009).

Thus, mixotrophy in some symbionts is a complementary strategy to maintain the carbon stock when the supply of inorganic carbon is limited. In such cases, they recycle host metabolic products (Seah et al. 2019). So, it is also possible in the case of clam like $P$. erosa to harbour obligate autotrophic to heterotrophic bacteria which are able to perform varying degree of mixotrophy linked to anaplerotic reactions.

Average rate of carbon fixation was the lowest during post-spawning. However, contrary to other seasons, mantle was relatively more efficient than gill and foot (Fig. 6). In this phase, bivalves were characterized by the lowest body mass (Podgorsek and Imhoff 1999) which is also evident in this study (Supplementary Table 2). Though the tissues regained the $\mathrm{S}_{2} \mathrm{O}_{3}{ }^{2-}$ uptake potential and associated 
bacterial abundance in this phase, the $\mathrm{HCO}_{3}$-uptake rate was low. As the animals are spent, the use of complementary nutrition would be minimal. High TOC concentration up to $4 \%$ during post-spawning in the ambient sediment of $P$. erosa also decreases the need for inorganic carbon fixation by its bacterial associates. Besides, the lower concentration of ambient dissolved oxygen due to higher salinity could slow down $\mathrm{HCO}_{3}{ }^{-}$uptake synchronizing with the changing physiology of the clam. At this stage, the existing mechanism of filter feeding could be enough for sustenance.

Since, most of the studies on $\mathrm{HCO}_{3}{ }^{-}$uptake by chemoautotrophic fauna have been represented as rate $\mathrm{g}$ wet $\mathrm{wt}^{-1}$ of the tissue. The maximum $\mathrm{HCO}_{3}{ }^{-}$uptake rate of 83 nmole $\mathrm{C} \mathrm{g}$ wet $\mathrm{wt}^{-1} \mathrm{~h}^{-1}$ in $P$. erosa was compared to that of hydrothermal vent and seep invertebrates. This rate in $P$. erosa was lower than the estimated rate of the provannid gastropod Ifremerianautilei of Lau Basin which was $700 \mathrm{nmole} \mathrm{C} \mathrm{g} \mathrm{wet}$ $\mathrm{wt}^{-1} \mathrm{~h}^{-1}$ (Beinart et al., 2015). The value in this study was also lower than that of the clam Calyptogena magnifica from Galápagos Rift which showed 900 nmole C g wet wt ${ }^{-1} \mathrm{~h}^{-1}$ Childress (Childress et al. 1991; Henry et al. 2008). The tubeworm Ridgeia piscesae from JFR vents and Lamellibrachia cf. luymesi from cold seep were able to take up 3.5 and $2.4 \mu$ mole $\mathrm{C} \mathrm{g}$ wet $\mathrm{wt}^{-1} \mathrm{~h}^{-1}$ at the expense of $\mathrm{H}_{2} \mathrm{~S}$ (Freytag et al. 2001; Nyholm et al. 2008). The vent mussel Bathymodiolus brevior and the clam Solemya reidi from the sludge outfall in Santa Monica Bay also exhibited closer rates of 1.4 and $2.4 \mu$ mole $\mathrm{C} g$ wet $\mathrm{wt}^{-1} \mathrm{~h}^{-1}$, respectively. The maximum reported rate of $26.8 \mu$ mole $C \mathrm{~g}_{\text {wet }} \mathrm{wt}^{-1} \mathrm{~h}^{-1}$ in the vent tube worm Riftiapachyptila and $24.7 \mu$ mole $\mathrm{C} \mathrm{g}$ wet $\mathrm{wt}^{-1} \mathrm{~h}^{-1}$ in the snail Alviniconchahessler (Girguis and Childress 2006; Girguis and Childress 2011) were 3 orders higher than the rate obtained for $P$. erosa. Muddy clam Myrteaspinifera from Norway exhibited chemosynthetic rate at the expense of $\mathrm{H}_{2} \mathrm{~S}$ ranging from 72 to 96 nmole $\mathrm{C} g$ wet $\mathrm{wt}^{-1} \mathrm{~h}^{-1}$. Rate showed by this deep lying clam found at $>30$-meter depth (Dando et al $1985)$ is close to the rate of $P$. erosa. Also, the rate reported for cold seep mytilid from the Gulf of Mexico ${ }^{53}$ falls within the range shown by $P$. erosa. Estimated value of average carbon uptake by 10 individuals $\mathrm{m}^{-2}$ of $P$. erosa (standing stock of $1 \mathrm{~kg}$ ) over the year constitutes $24 \mathrm{mg} \mathrm{C} \mathrm{m}^{-2}$. It is also interesting to note that $\mathrm{S}_{2} \mathrm{O}_{3}{ }^{2-}$ uptake rate of $P$. erosa was nearly 100 times more than invertebrates from other reducing habitats like vents and seeps, but $\mathrm{CO}_{2}$ fixation is on the lower end of the range suggesting a lower efficiency of the chemoautotrophic bacterial associates. This could be due to the prevalence of the organically rich ecosystem which has lower rates of chemoautotrophy as opposed to oligotrophic region as in the Central Indian Basin (Das et al. 2011) which could promote higher rates.

Besides, the availability of high concentration of electron donors and acceptors, scarcity of organic carbon as substrate and prevailing higher temperatures facilitate much higher rates of chemoautotrophy at most hydrothermal vents. However, dark carbon fixation in mangrove ecosystem is mainly governed by the concentration of electron donors. Though there are no previous records on the role of foot and mantle tissues to chemoautotrophy, our studies clearly showed that the mantle could be the main contributor during post-spawning. However, large standard deviations encountered in the measurement suggest high spatial heterogeneity within the tissue (Duperron et al. 2013). 
This study highlights that, the different tissue of $P$. erosa along with their bacterial associates, were capable of fixing inorganic carbon at the expense of reduced sulphur compound. Though $\mathrm{S}_{2} \mathrm{O}_{3}{ }^{2-}$ uptake was high during the pre-spawning phase in preparation for the ensuing spawning phase, $\mathrm{HCO}_{3}{ }^{-}$uptake was maximum during spawning period coinciding with the monsoon. Ambient geochemistry of the sediment showing high concentrations of electron donors and acceptors in non-limiting concentrations during spawning period, suggests their role in enhancing chemosynthetic production. This chemosynthetic conversion of $\mathrm{CO}_{2}$ by these clams especially during spawning could serve as a supplementary source of nutrition constituting about $24 \mathrm{mg} \mathrm{C} \mathrm{m}^{-2}$ when the clams are physiologically feeble.

Most of the studies on chemosynthesis till date have revolved around hydrothermal vents and cold seep systems or wetlands like salt marshes and sea grass meadows. Such studies have not yet been covered in the Indian mangrove ecosystem. It throws light on the extent of chemoautotrophy prevailing in mixotrophic representative of family Cyrenidae and prompts future attempts on other sub surface dwelling sediment fauna. Participation of mixotrophs in chemoautotrophy could have wide ranging implications in climate modelling and geoengineering.

\section{Future Scope}

Down core profiling of both $\mathrm{S}_{2} \mathrm{O}_{3}{ }^{2-}$ oxidizing potential and $\mathrm{HCO}_{3}{ }^{-}$uptake would help compare activity in sediments with the clam and help appreciate their contribution to carbon fixation on a wider spatial scale. Studies could be extended to other electron donors to understand the full chemoautotrophic potential of the clams and sediment associated bacteria. Including other fauna in the study would help in understanding chemosynthesis in the mangrove sediment more holistically. Participation of mixotrophic processes in sediments could be considered for climate models.

\section{Declarations}

Acknowledgements We thank the former and present Directors CSIR-NIO, Goa for encouragement and facilities. Wild life Division and Forest Department, Goa permitted the sample collection. We are extremely grateful to Dr. C T Achuthankutty (Former Scientist, CSIR-NIO) for improving the language and grammar of the manuscript. Dr. Colleen Cavanaugh from Department of Organismic and Evolutionary Biology, Harvard University, MA, USA is thanked for useful post symposium ( $6^{\text {th }}$ International Symposium on Chemosynthesis 2017) discussion with Tresa. Their deliberations on this subject form the central theme of the paper. This manuscript has NIO communication number xxxx.

Authors' contributions Loka Bharathi P A conceptualizing, designing study, planning, methodology, supervising, data curation, initial drafting and eventual finalisation. TresaRemya A. Thomas: Field study, laboratory experiments, analyzed data, drafting and finalizing. Tanya Singh and Tamil S. Kalaimani assisted in the field, laboratory experiments and data processing. Nandakumar $\mathrm{H}$. Khadge provided the 
geotechnical data. Mamatha S. Shivaramu was closely associated with field and laboratory work and manuscript preparation. Maria-Judith B. D. Gonsalves was involved in scientific input required during manuscript preparation and finalization.

Funding LPA had received the emeritus Scientist Fellowship (Scheme number:21(086)/11/EMR-II) from Council of Scientific and Industrial Research (CSIR), India. TRAT was awarded Senior Research Fellowship, from Council of Scientific and Industrial Research (CSIR), India and AcSIR, NIO for official support to pursue the work. All other authors have no relevant financial interests to disclose

The data availability statement All data generated or analyzed during this study are available from the corresponding author on reasonable request. All data generated or analyzed during this study are included in this published article [and its supplementary information files].

Conflicts of interests The authors declare that there are no conflicts of interest

Ethical approval This article does not contain any studies with human participants or animals

\section{References}

1. Anderson AE, Childress JJ, Favuzzi J (1987) Net uptake of $\mathrm{CO}_{2}$ driven by sulfide and thiosulfate oxidation in the bacterial symbiont containing clam Solemya reidi. J Exp Biol 133:1-31

2. Arndt C, Gaill F, Felbeck H (2001) Anaerobic sulfur metabolism in thiotrophic symbioses. J Exp Biol 204:741-750.

3. ASTM (1978) Annual book of ASTM standards. Philadelphia. 570 p.

4. Attri K, Kerkar S, LokaBharathi PA (2011) Ambient Iron concentration regulates the sulfate reducing activity in the mangrove swamps of Diwar, Goa, India. Estuar Coast Shelf Sci 95:156-

164. https://doi.org/10.1016/j.ecss.2011.08.030

5. Azam F, Sajjad MH (2005) Colorimetric determination of organic carbon in soils by dichromate digestion in a microwave oven. Pak J Biol Sci 8:596-

598. https://dx.doi.org/10.3923/pjbs.2005.595.598

6. Beinart RA, Gartman A, Sanders JG, Luther GW, Girguis PR (2015) The uptake and excretion of partially oxidized sulfur expands the repertoire of energy resources metabolized by hydrothermal vent symbioses. Proc Biol Sci 282:2811-28. https://doi.org/10.1098/rspb.2014.2811

7. Caro A, Gros O, Got P, De Wit R, Troussellier M (2007) Characterization of the population of the sulfuroxidizing symbiont of Codakiaor bicularis (bivalvia, lucinidae) by single-cell analyses. Appl Environ Microbiol 73:2101-2109. https://doi.org/10.1128/AEM.01683-06

8. Chau JF, Bagtzoglou AC, Willig MR (2011) The effect of soil texture on richness and diversity of bacterial communities. Environ Forensics 12:333-341.

https://doi.org/10.1080/15275922.2011.622348 
9. Caporaso JG et al (2010). QIIME allows analysis of high-throughput community sequencing data. Nat. Methods, 7, 335-336. https://doi.org/10.1038/nmeth.f.303

10. Childress JJ, Fisher CR, Favuzzi JA, Sanders NK (1991) Sulfide and carbon dioxide uptake by the hydrothermal vent clam, Calypto genamagnifica and its chemoautotrophic symbionts. Physiol Zool 64:1444-1470. https://www.jstor.org/stable/30158224

11. Childress JJ, Girguis PR (2011) The metabolic demands of endosymbiotic chemoautotrophic metabolism on host physiological capacities. J Exp Biol 214:312-325. https://doi.org/1010.1242/jeb.049023

12. Christo SW, Ivachuk CS, Ferreira-Junior AL, Absher TM (2016) Reproductive periods of Lucina pectinata (Bivalve; Lucinidae) in the Paranaguá estuarine complex, Parana. Brazil. Braz J Biol 76:300-306. http://dx.doi.org/10.1590/1519-6984.12514

13. Clemente S, Ingole BS (2006) Recruitment of mud clam Polymesoda erosa (Solander, 1876) in a mangrove mud flat. In: National Seminar on Environmental Scenario: Challenges and solutions, Rewa, Madhya Pradesh $60 \mathrm{p}$.

14. Clemente S, Ingole B (2009) Gametogenic development and spawning of the mud clam Polymesoda erosa (Solander, 1876) at Chorao Island, Goa. Mar Biol Res 5:109-121. https://doi.org/ $10.1080 / 17451000802317709$

15. Clemente S, Ingole B (2011) Recruitment of mud clam Polymesoda erosa (Solander, 1876) in a mangrove habitat of Chorao Island, Goa. Braz J Oceanogr 59: 153162. http://dx.doi.org/10.1590/S1679-87592011000200004

16. Dando PR, Southward AJ, Southward EC, Terwilliger NB, Terwilliger RC (1985) Sulphur oxidizing bacteria and hemoglobin in gills of the bivalve mollusk Myrteaspinifera. Mar Ecol Prog Ser 23: 85-98. https://www.jstor.org/stable/24817599

17. Dattagupta $S$ et al (2009) A novel symbiosis between chemoautotrophic bacteria and a fresh water cave amphipod. ISME J 3:935-943. https://doi.org/10.1038/ismej.2009.34

18. Das A, Sujith PP, Mourya BS, Biche SU, LokaBharathi PA (2011) Chemosynthetic activity prevails in deep sea sediments of the Central Indian Basin. Extremophiles 15:177189. https://doi.org/0.1007/s00792-010-0346-z

19. Distel DL et al (1988) Sulfur-oxidizing bacterial endosymbionts: analysis of phylogeny and specificity by $16 \mathrm{~S}$ rRNA sequences. $J$ bacterial 170:2506-

2510. https://doi.org/10.1128/jb.170.6.2506-2510.1988

20. Dubilier N, Bergin C \& Lott C (2008) Symbiotic diversity in marine animals: the art of harnessing chemosynthesis. Nat Rev Microbiol 6:725-740. https://doi.org/10.1038/nrmicro1992

21. Duperron $S$ et al (2013) An overview of chemosynthetic symbiosis in bivalves from the north Atlantic and Mediterranean Sea. Biogeosci 10:3241-3267. https://doi.org/10.5194/bg-10-3241-2013

22. Durand P, Gros O, Frenkiel L \& Prieur D (1996) Phylogenetic characterization of sulfur-oxidzing bacterial endosymbionts in three tropical Lucinidae by $16 \mathrm{~S}$ rDNA sequence analysis. Mol Mar Biol Biotechnol 5:33-42. 
23. Fallon RD, Newell SY, Hopkinson CS (1983) Bacterial production in marine sediments: will cellspecific measures agree with whole - system metabolism? Mar Ecol Prog Ser 11: 119-127. https://doi.org/10.1007/BF02015053

24. Fenchel TM, Riedl RJ (1970) The sulfide system: a new biotic community underneath the oxidized layer of marine sand bottoms. Mar Biol 7:255-268. https://doi.org/10.1007/BF00367496

25. Feng X, Tang KH, Blankenship RE, Tang YJ (2010) Metabolic flux analysis of the mixotrophic metabolisms in the green sulfur bacterium Chlorobaculum tepidum. J Biological Chem 285:3954439550. https://doi.org/10.1074/jbc.M110.162958

26. Fernandes SO, Michotey VD, Guasco S, Bonin PC, LokaBharathi PA (2012) Denitrification prevails over anammox in tropical mangrove sediments. Mar Environ Res 74:9-

19. https://doi.org/10.1016/j.marenvres.2011.11.008

27. Fernandes SO, Gonsalves MJ, Michotey VD, Bonin PC, Lokabharathi PA (2013) Denitrification activity is closely linked to the total ambient Fe concentration in mangrove sediments of Goa, India. Estuar Coast Shelf Sci 131:64-74. https://dx.doi.org/10.10382Fsrep00419

28. Fisher CR, Childress JJ, Oremland RS, Bidigare RR (1987) The importance of methane and thiosulfate in the metabolism of the bacterial symbionts of two deep-sea mussels. Mar Biol 96:5971. https://doi.org/10.1007/BF00394838

29. Frenkiel L, Gros O, Moueza M (1996) Gill structure in Lucina pectinata (Bivalvia: Lucinidae) with reference to hemoglobin in bivalves with symbiotic sulphur- oxidizing bacteria. Mar Biol 125:511524 https://doi.org/10.1007/BF00353264

30. Freytag JR et al (2001) A paradox resolved: Sulfide acquisition by roots of seep tubeworms sustains net chemoautotrophy. Proc Nat Acad Sci USA 98:13408-

13413. https://doi.org/10.1073/pnas.231589498

31. Girguis PR, Childress JJ (2006) Metabolite uptake, stoichiometry and chemoautotrophic function of the hydrothermal vent tubeworm Riftia pachyptila: responses to environmental variations in substrate concentrations and temperature. J Exp Biol 209:3516-3528. https://doi.org/10.1242/jeb.02404

32. Gros O, Darrasse A, Durand P, Frenkiel L, Moueza M (1996) Environmental transmission of sulfuroxidizing bacterial gill endosymbiont in the tropical lucinid bivalve Codakia orbicularis. Appl Environ Microbiol 62:2324-2330. PMCID:PMC168012

33. Gros O, Duplessis MR, Felbeck H (1999) Embryonic development and endosymbiont transmission mode in the symbiotic clam Lucinoma aequizonata (Bivalvia: Lucinidae). Invertebr Reprod Dev 36:93-103. https://doi.org/10.1080/07924259.1999.9652683

34. Hansen NW (1973). Official standardized and recommended methods of analysis. London: The society of analytical chemistry. $897 p$.

35. Henry MS, Childress JJ, Figueroa D (2008) Metabolic rates and thermal tolerances of chemoautotrophic symbioses from Lau Basin hydrothermal vents and their implications for species distributions. Deep-Sea Res 155:679-695. https://doi.org/10.1016/j.dsr.2008.02.001 
36. Hobbie JE, Daley RJ, Jasper S (1977) Use of Nucleopore filters for counting bacteria by fluorescence microscopy. Appl Environ Microbiol 33:1225-1228.

37. Ingole BS, KrishnaKumari L, Ansari ZA, Parulekar AH (1994) New record of mangrove clam Geloinaerosa (Solander, 1786) from the west coast of India. J Bom Natl Hist Soc 91: 338-339. http://drs.nio.org/drs/handle/2264/7401

38. Knap AH, Michaels A, Close AR, Ducklow H, Dickson AG (1996) Protocols for the joint global ocean flux study (JGOFS) core measurements. Report, UNESCO, https://doi.org/10.10013/epic.27912.d001

39. Kogure K, Simidu U, Taga N (1984) An improved direct viable count method for aquatic bacteria. Arch Hydrobiol 102:117-122,

40. Laurent MCZ, Gros O, Brulport JP, Gaill F, Bris N Le (2009) Sunken wood habitat for thiotrophic symbiosis in mangrove swamps. Mar Environ Res 67:83-

88. https://doi.org/10.1016/j.marenvres.2008.11.006

41. Lebata MJ (2001) Oxygen, sulphide and nutrient uptake of the mangrove mud clam Anodontiae dentula (Family: Lucinidae). Mar poll Bull 42:1133-1138. https://doi.org/10.1016/s0025326x(01)00113-8 .

42. Lebata J \& Primavera JH (2001) Gill structure, anatomy and habitat of Anodontia edentula: Evidence of endosymbiosis. J Shellfish Res 20:1273-1278. http://hdl.handle.net/10862/1855

43. LokaBharathi PA, Chandramohan D, Nair S (1988) A preliminary study of thiosulfate oxidizing bacteria as dinitrifiers in the Arabian Sea. Geomicrobiol J 6:195-

207. https://doi.org/10.1080/01490458809377839

44. LokaBharathi PA (1989). The occurrence of denitrifying colourles ssulphur oxidizing bacteria in marine waters and sediments as shown by the agar shake technique. FEMS Microb Ecol 62:335-342 https://doi.org/10.1016/0378-1097(89)90001-3

45. LokaBharathi PA, Nair S, De Souza MJBD, Chandramohan D (1999). Truce with Oxygen Anaerobiosis Out compete Aerobiosis in the Antarctic Lacustrine Bacteria. Curr Sci 76:1585-1587. http://drs.nio.org/drs/handle/2264/1838

46. Meehan B (1982). Shell Bed to Shell Midden. Canberra: Australian Institute of Aboriginal Studies, Aboriginal Studies Press 189 p, https://trove.nla.gov.au/version/46386757

47. Morton B (1976) The biology and functional morphology of the Southeast Asian mangrove bivalve, Polymesoda (Geloina) erosa (Solander, 1786) (Bivalvia: Corbiculidae). Can J Zool 544:482-500. http://drs.nio.org/10.1139/z76-055

48. Naik SS et al (2016) Relationship of sediment-biogeochemistry, bacterial morphology, and activity to geotechnical properties in the Central Indian Basin. Mar Georesour Geotec 34:21-32. https://doi.org/10.1080/1064119X.2014.954680

49. Nedwell DB, Blackburn TH, Wiebe WJ (1994) Dynamic nature of the turnover of organic carbon, nitrogen and sulphur in the sediments of a Jamaican mangrove forest. Mar Ecol Prog Ser 110:223231. https://doi.org/10.3354/meps 110223 
50. Nelson DC, Wirsen CO, Jannasch HW (1989) Characterization of large, autotrophic Beggiatoa species abundant at the hydrothermal vents of the Guaymus Basin. Appl Environ Microbiol 55:2902917. PMCID: PMC203190

51. Nielsen PH. De Muro MA, Nielsen JL (2000) Studies on the in situ physiology of Thiothrix spp. present in activated sludge. Env Microbiol 2:389-398. 10.1046/j.1462-2920.2000.00120.x

52. Nyholm SV, Robidart J, Girguis PR (2008) Coupling metabolite flux to transcriptomics: Insight into the molecular mechanisms underlying primary productivity by the hydrothermal vent tubeworm Ridgeia piscesae. Biol Bull 214:255-265. https://doi.org/10.2307/25470667

53. Odintsova EV, Wood AP, Kelly DP (1993) Chemolithoautotrophic growth of Thiothrix ramosa. Arch Microbiol 160:152-157. https://doi.org/10.1007/BF00288718

54. Oren A (2010) Microbial metabolism: Importance for environmental biotechnology. In: Wang L, Ivanov V, Tay JH, editors. Hand book of environmental engineering. 10. Totowa, N.J. Humana Press. P. 193-255. https://doi.org/10.1002/jctb.1268

55. Ott, J.A., Bright, M. \& Schiemer, F. (1998). The Ecology of a Novel Symbiosis between a Marine Peritrich Ciliate and Chemoautotrophic Bacteria. Mar. Ecol.,19, 229243, https://doi.org/10.1111/j.1439-0485.1998.tb00464.x

56. Pimenov NV, Kalyuzhnaya MG, Khmelenina VN, Mityushina LL, Trotsenko YA (2002). Utilization of methane and carbon dioxide by symbiotic bacteria in gills of Mytilidae (Bathymodiolus) from the Rainbow and Logatchev Hydrothermal fields on the Mid-Atlantic Ridge. Microbiol 71:681689. https://doi.org/10.1023/A:1020519105618

57. Podgorsek L, Imhoff JF (1999) Tetrathionate production by sulfur oxidizing bacteria and the role of tetrathionate in the sulfur cycle of Baltic Sea sediments. Aquat Microbial Ecol 17:255-265. https://doi.org/10.3354/ame017255

58. Rivonker CU, Parulekar AH (1995) Proximate biochemical composition and caloric potential in the raft grown green mussel Perna viridis. J Mar Biol Assoc India 37:231-

236. http://drs.nio.org/drs/handle/2264/2304

59. Rhoads DC, Boyer LF (1982) The Effects of Marine Benthos on Physical Properties of Sediments. In: McCall PL, Tevesz MJS (eds.). Animal-Sediment Relations. Topics in Geobiol, Springer, Boston, MA, 100, 3-52,

60. Robertson Al (1986) Leaf-burying crabs: their influence on energy flow and export from mixed mangrove forests (Rhizophoraspp.) in northeastern Australia. J Exp Mar Biol Ecol 102:237248. https://doi.org/10.1016/0022-0981(86)90179-6

61. Sahoo K, Dhal NK (2009) Potential microbial diversity in mangrove ecosystems: A review. Indian Mar Sci 38: 249-256. http://hdl.handle.net/123456789/4675

62. Sahoo G, Suchiang SR, Ansari ZA (2013) Meiofauna-mangrove interaction: A pilot study from a tropical mangrove habitat. Cah Biol Mar 54:349-358. http://drs.nio.org/drs/handle/2264/4346

63. Sarma VV et al. (2012) Carbon dioxide emissions from Indian monsoonal estuaries. Geophys Res Lett 39:L03602, https://doi.org/10.1029/2011GL050709 
64. Seah BK et al (2019) Sulfur-oxidizing symbionts without canonical genes for autotrophic $\mathrm{CO}_{2}$ fixation. mBio 10:e01112-19. https://doi.org/10.1128/mBio.01112-19

65. Strickland JDH, Parson TRA (1965) Manual of sea water analysis. $2^{\text {nd }}$ ed. Fish Res Bd Canada Bull p. 125-203.

66. Tang KH, Feng X, Tang YJ, Blankenship RE (2009) Carbohydrate metabolism and carbon fixation in Roseobacter denitrificans OCh114. PLoS One 4:e7233 https://doi.org/0.1371/journal.pone.000723

67. Thomas TRA, Das A, LokaBharathi PA (2018) A Review on the phylogeography of potentially chemoautotrophic bacteria from major vent and seep fauna and their contribution to primary production. Geomicrobiol J 35:612-634. https://doi.org/10.1080/01490451.2018.1440035

68. Truper HG, Schlegel HG (1964) Sulfur metabolism in Thiorhodaceae 1. Quantitative measurements on growing cells of Chromatiumokenii. Antonie van Leeuwenhoek J Microbiol Serol 30:225-238. https://dx.doi.org/10.1007/bf02046728

69. Tuttle JH Jannasch HW (1977) Thiosulfate stimulation of microbial dark assimilation of carbon dioxide in shallow marine waters. Microb Ecol 4:9-25. https://doi.org/10.1007/BF02010426

70. Vrijenhoek RC (2010) Genetics and Evolution of Deep-Sea Chemosynthetic Bacteria and Their Invertebrate Hosts Steffen K (Ed) The Vent and Seep Biota. Springer, Netherlands 33:1549. https://doi.org/10.1007/978-90-481-9572-5_2

\section{Figures}




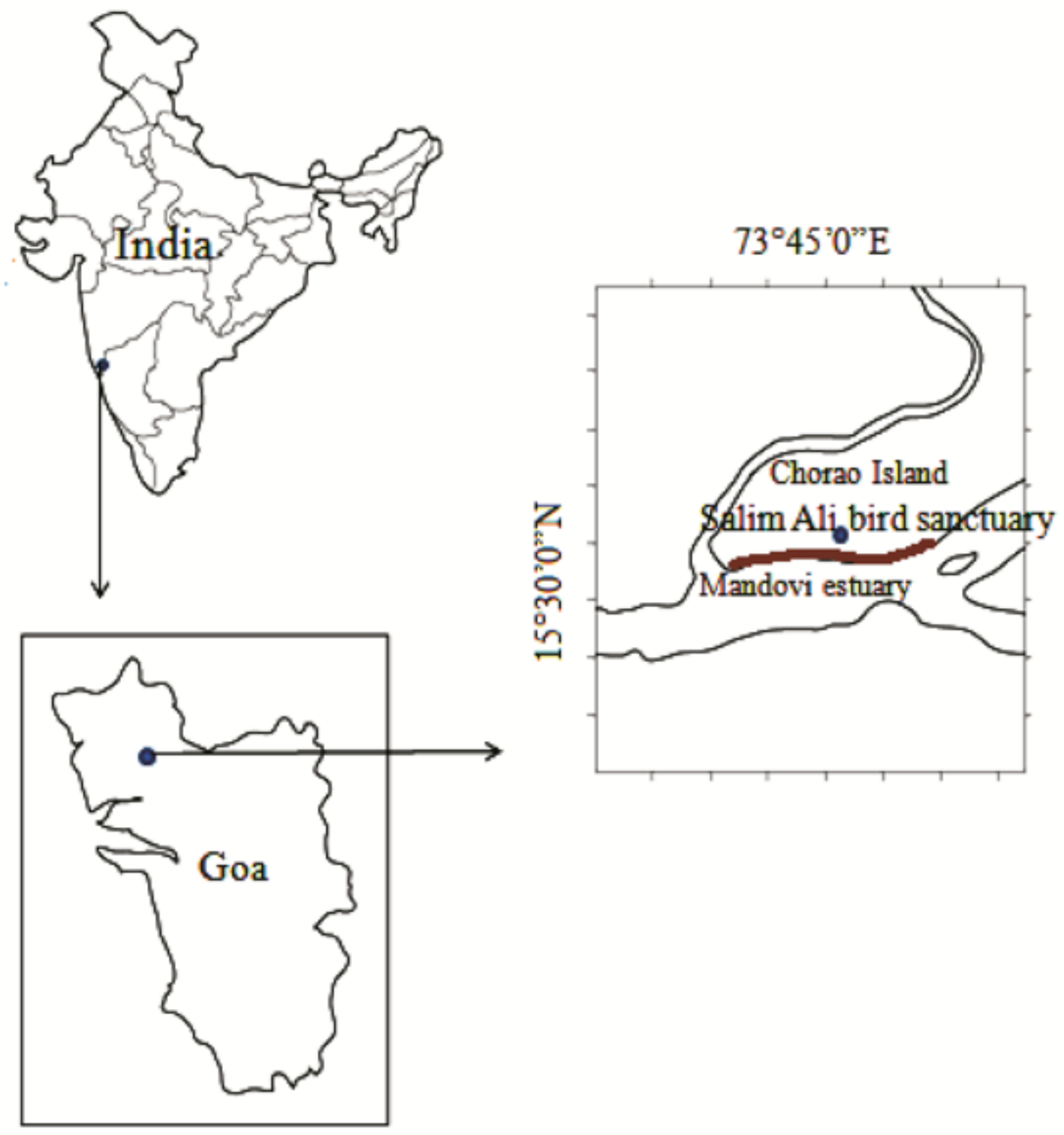

Figure 1

Sampling site Brown stretch represents the high tide region where clams are available Note: The designations employed and the presentation of the material on this map do not imply the expression of any opinion whatsoever on the part of Research Square concerning the legal status of any country, territory, city or area or of its authorities, or concerning the delimitation of its frontiers or boundaries. This map has been provided by the authors. 


\section{Figure 2}

Please see the Manuscript file for the complete figure caption.

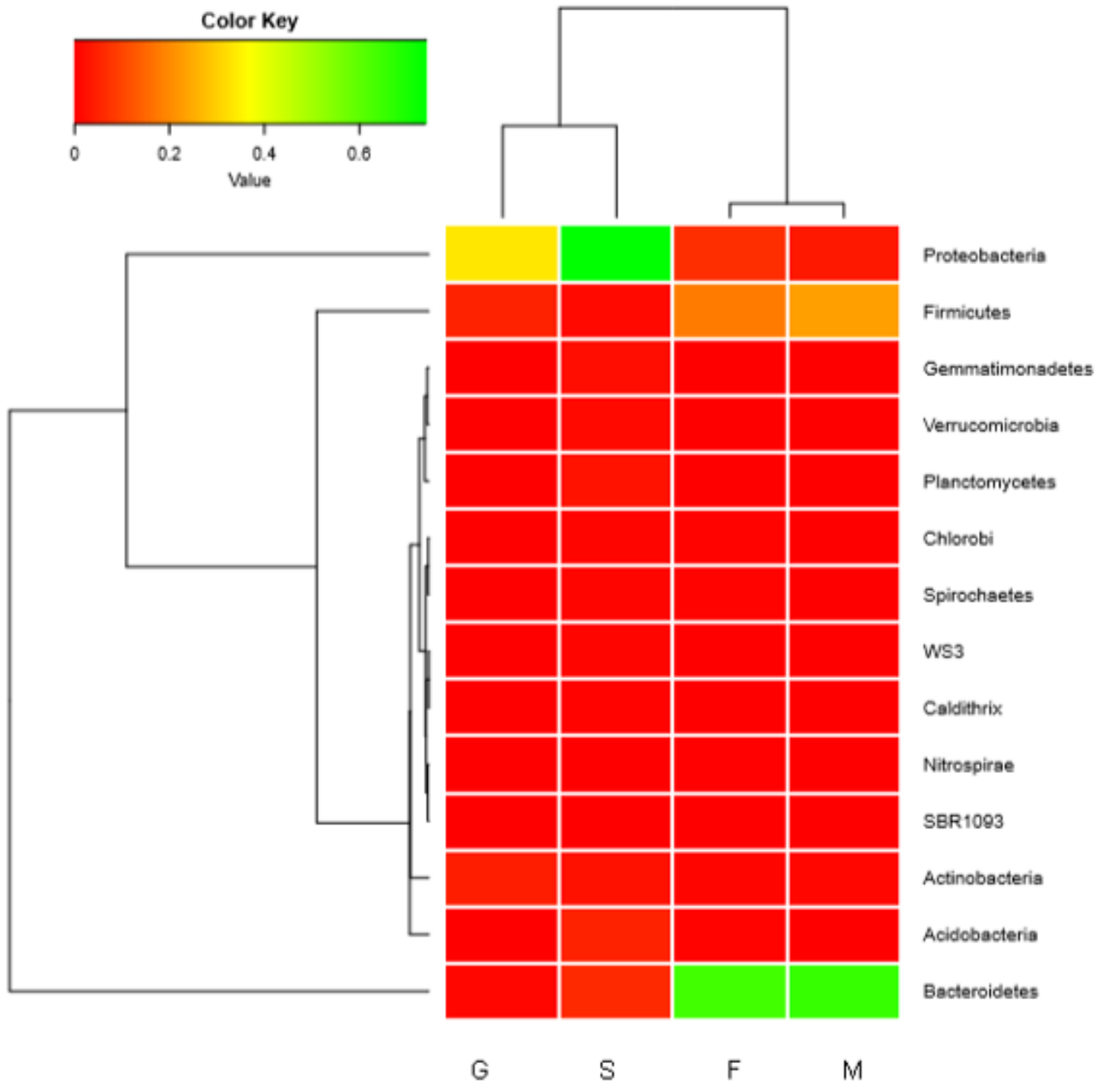


Figure 3

Heat map showing the taxonomic lineage of microbial communities at phylum level in gill, foot and mantle tissues of P. erosa and its ambient sediment ( $0-2 \mathrm{~cm}$, bss) G - gill; S-sediment; F-foot; M-mantle; bss-below surface sediment; The colour code indicates the increase in range of relative abundance of sequence reads from red to green.

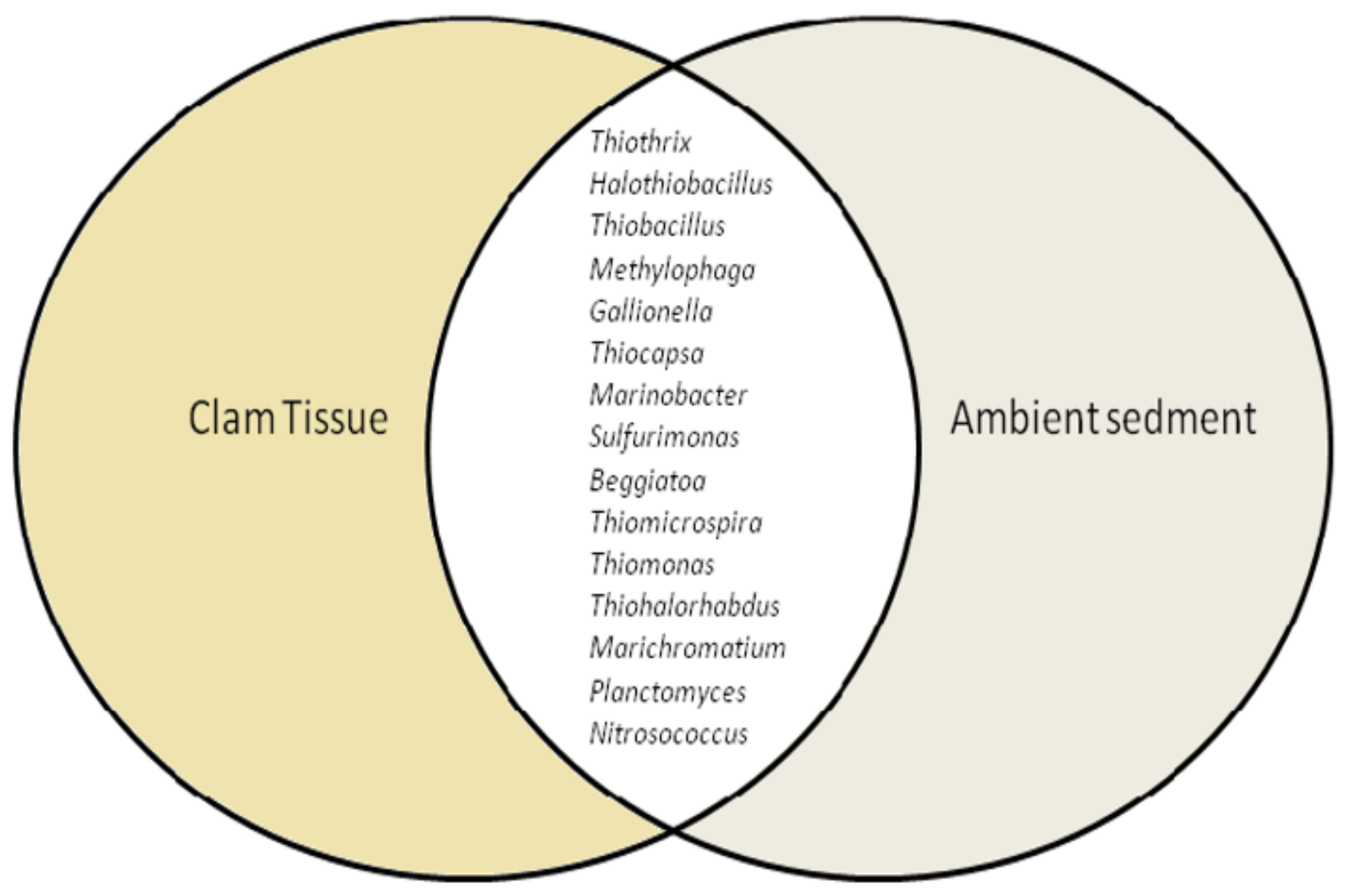

Figure 4

Pictorial representation of dominant chemoautotrophic archaeal and bacterial genera common in clam tissue and ambient sediment. 

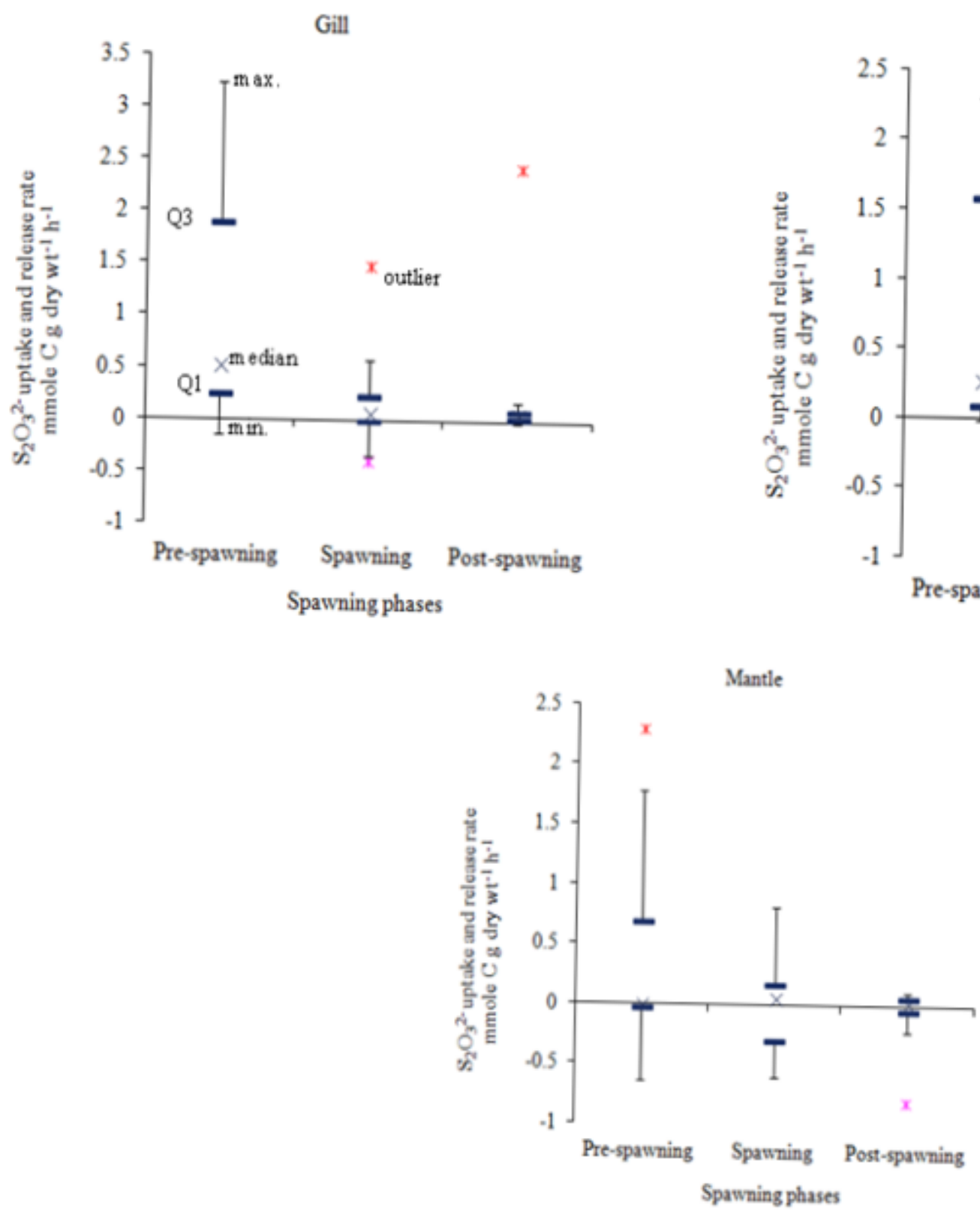

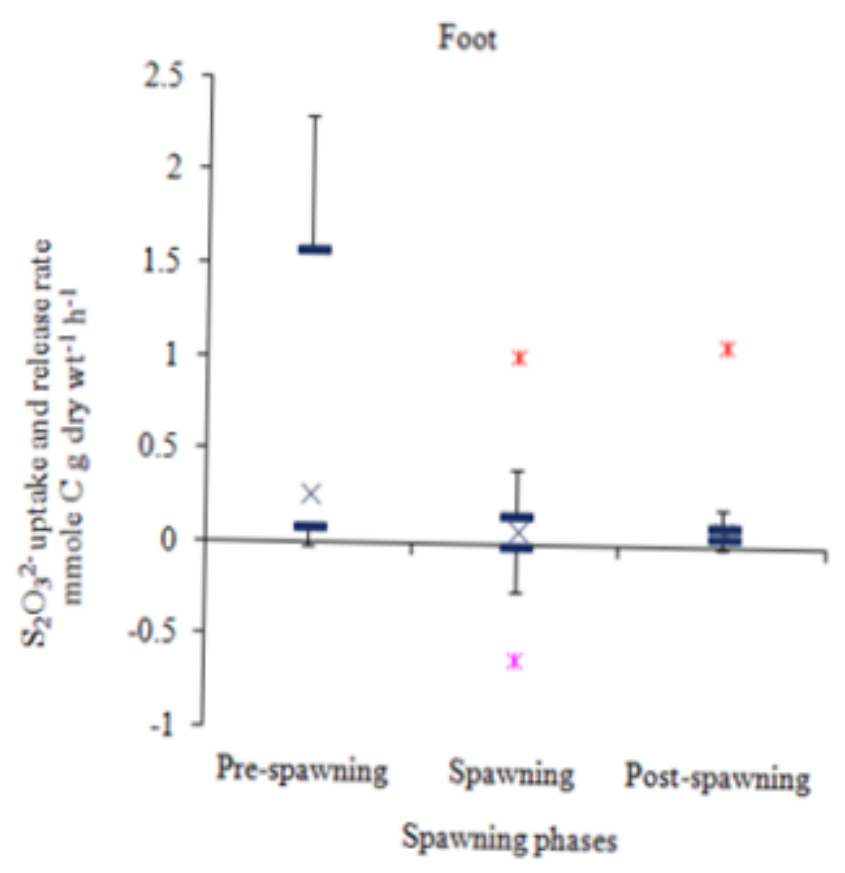

\section{Figure 5}

Box and Whisker plot showing the range and median of thiosulphate utilization through the phases of spawning in different tissues of P. erosa Q1 and Q3 represent the first and third quartile of the dataset; $\mathrm{n}=$ 26 to 28 (pre-spawning phase); $n=20$ to 21 (spawning phase); $n=11$ to 12 (post-spawning phase) for each tissue at each time interval; Positive value indicates thiosulphate uptake rate and negative value indicates thiosulphate release rate. With mantle, below zero relates to the added level of thiosulphate. Thus thiosulphate uptake below zero is possible because of the "release" by the tissue 

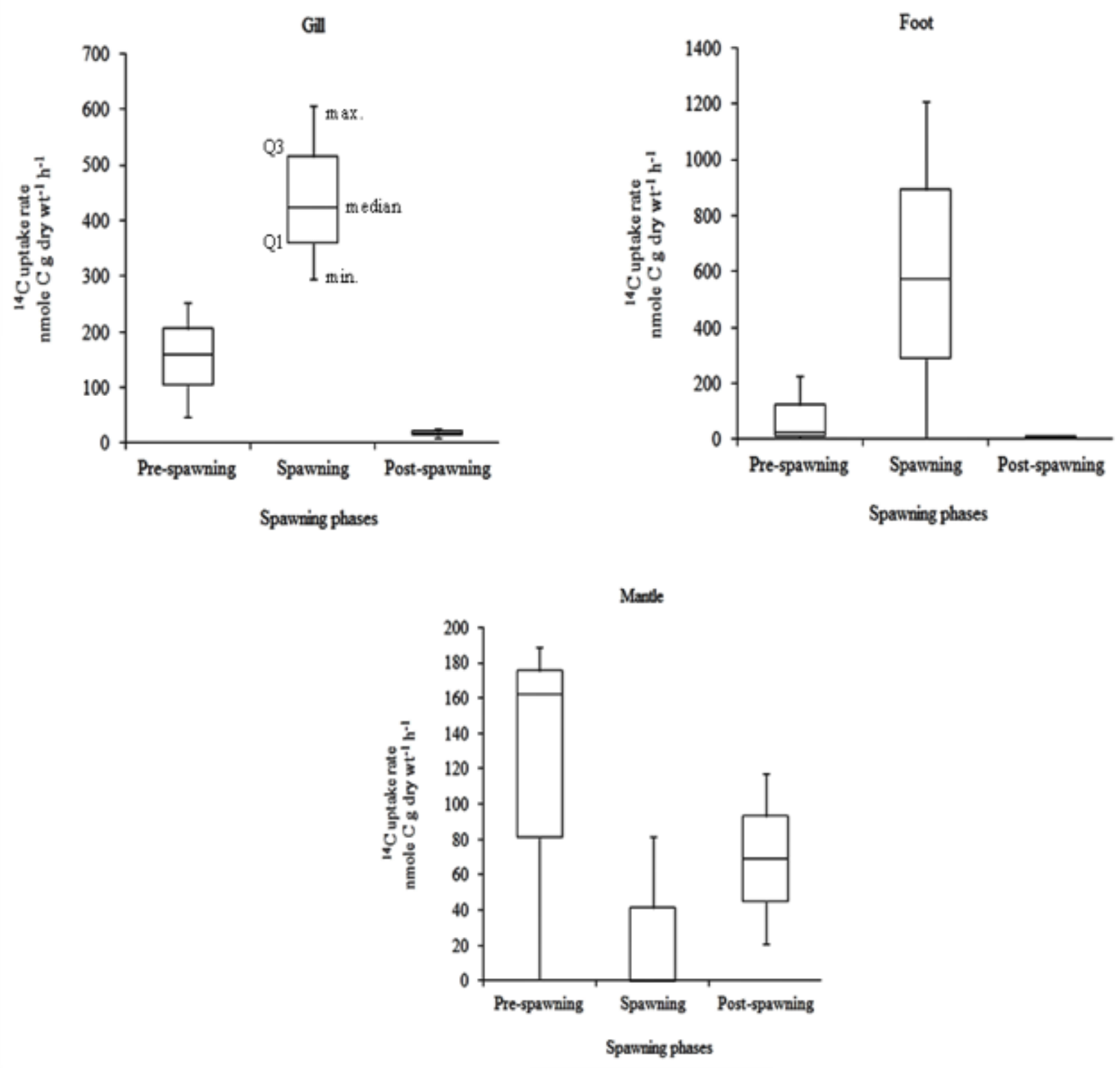

\section{Figure 6}

Box and Whisker plot showing the range and median of bicarbonate (14C) uptake in gill, foot and mantle tissue of P. erosa during different spawning phases. Q1 and Q3 represent the first and third quartile of the dataset; The trend of HCO3- uptake is reverse of S2O32-uptake i.e. maximum HCO3- uptake is during minimum S2032 uptake; The number of replicates (n) vary from 2 (post-spawning) to 3 (pre-spawning, spawning) for each tissues at each time interval.

\section{Supplementary Files}

This is a list of supplementary files associated with this preprint. Click to download.

- attachmenttomanuscriptALU.docx 